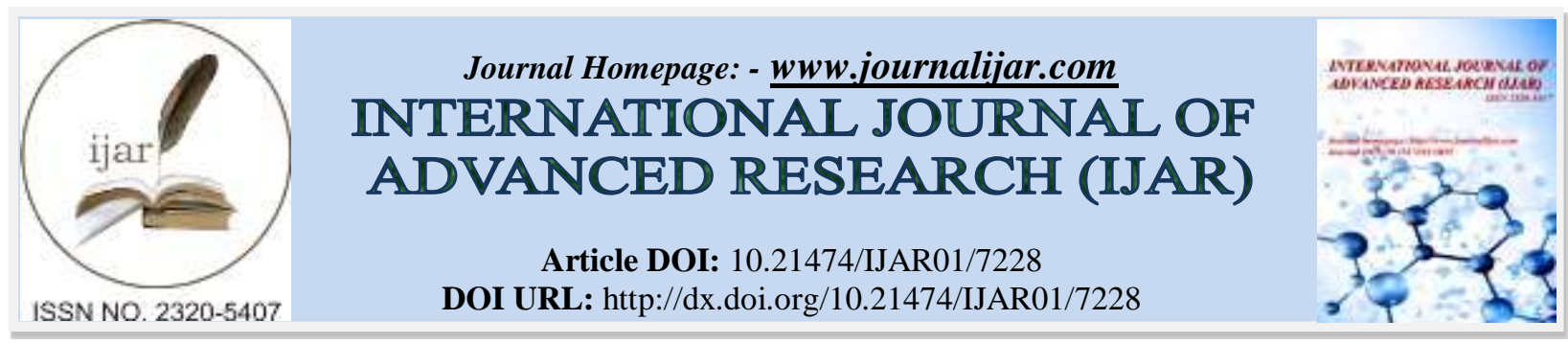

RESEARCH ARTICLE

\title{
THE IMPACT OF SOCIAL ENTREPRENEURSHIP ON NATIONAL DEVELOPMENT (INDIA).
}

\section{Dr. Sonia Justin Raj ${ }^{1}$, Ms. Amrutha Sajeevan ${ }^{2}$ and Dr. Shazli Sheikh ${ }^{2}$.}

1. Assistant Professor D.Y. Patil University School of Management, Sector-4, CBD Belapur, Navi Mumbai, India.

2. D.Y. Patil University School of Management, Sector-4, CBD Belapur, Navi Mumbai, India.

\section{Manuscript Info}

Manuscript History

Received: 07 April 2018

Final Accepted: 09 May 2018

Published: June 2018

Keywords:-

Social entrepreneurship. National

Development, Social Enterprises.

\begin{abstract}
Social entrepreneurships are a ray of hope in a scourged and impoverished society as they largely contribute to providing a livelihood to people who could otherwise not have succeeded due to illiteracy, poverty and negligence. The fruits of globalization do not penetrate into lower communities of the Indian populace due to many political, social and economic disparities. Social entrepreneurs are providers of those means to develop the community and also earn by way of it. Rather than blaming the government, people themselves must come together and create such enterprises to develop oneself thereby aiding national development in all aspects.

This research has been done to understand the impact of social entrepreneurship on Nations development. This research has been undertaken with the help of 28 social enterprises wherein the analysis has been constructed by ways of a structured questionnaire to understand the impact that each enterprise has had on the economic and social development of the nation.
\end{abstract}

Copy Right, IJAR, 2018,. All rights reserved.

\section{Introduction:-}

India presently has become one of the fastest growing economies of the world with a Gross Domestic Product(GDP) being crossed the trillion dollar mark. With the celebration of the progress the fact shouldn't be overlooked that this kind of a development also many a times leads to certain negative aspects. The rapidly increasing depletion of environmental resources and the unequal resource allocation, and increasing disparity in society have become a challenge to the nation. In order to make the developments inclusive, the role of social entrepreneurs must be included. Social entrepreneurship is one of the most promising trends around the world. What exactly is social entrepreneurship? Social entrepreneurship is an activity or process wherein an entrepreneur identifies a social cause or need or an opportunity and thereby applies management techniques and business spirit to address that social need and then create a certain value to it.

The term "social entrepreneurship" may be new to many people, largely because of the lack of understanding of the difference between social work and social entrepreneurship. Profits do not play a major role here, whereas the level of impact created in the society is what matters to any social entrepreneur. A major drawback of many developing economies is the gap among socio-economic classes, lack of opportunities for the lower strata, and inefficient resource allocation. Hence, the world is in dire need of social entrepreneurs to ensure a holistic development of respective nations. Globalization and improved technologies are meant to be comforting to nation development but 
the underlying or rather ignored fact is that whether these facilities and opportunities reach every socio economic class and does this in any way contribute in alleviating poverty.

Taking the example of our nation, India, the government in a way remains helpless in certain scenarios wherein the system is plagued with corruption and bureaucracy and the constant urge to defame one another. Even after being the largest democracy of the world, there still exists a major gap between the rich and the poor. Businesses largely run on the sole motive of gains, expansions, overseas development etc. But thanks to companies like Infosys, Tata etc. who have sincere contribution towards corporate social responsibility. With the Government's policies regarding CSR, any private or public limited company with net worth of Rs500crore or an annual turnover of Rs 1,000 crore have to spend at least $2 \%$ of their average net profit towards CSR activities. But whether or not such activities are sincerely carried out by all companies and organizations remains a question mark.

Social entrepreneurship thrives and blooms only in an empowered environment. Their vision and mission largely is based upon this factor and the vision is aligned with people's interests. Social entrepreneurs are the change makers, the Nelson Mandelas' of today's world.

\section{Objectives:-}

1. To understand the need of social entrepreneurships in India

2. To study how revenue can be generated through social entrepreneurship

3. To analyze the effect of social entrepreneurships on lower economic classes

4. To understand the impact created by social entrepreneurs on employment and national development

\section{Literature Review:-}

1. Impact of social entrepreneurships in emerging economies, Indian CSR network by Manisha Bhatia: Social entrepreneurs commit to generate solutions for the most general and demanding problems faced by the society. They can also be termed as philantropreneurs because their work is a combination of philanthropy and sustainable solutions that help in providing notable changes in the economy. They fight against many social issues that were caused against the development process and try to eradicate those issues that act against the growth of the society. They commit to bring a difference in the society through their social initiatives. Social entrepreneurships is no longer a social welfare activity, it has become a global phenomenon. They help in reducing the burden on the government.

2. Social entrepreneurship in India, by Nikhil Menon, ET bureau dated 20 Feb, 2009. 01.18am IST. This piece of article explains how social entrepreneurships are based on business models that are created around low cost products and services that are made available, thus, resolve social inequities. The example stated were of AMUL and SEWA. It also states an example of rural BPO service that was started in the year 2007. This was in order to provide vocational training to rural youth.

3. Opportunities for social entrepreneurs in India, by Samiksha Jain, feature writer, Entrepreneur.com In this article, the writer focuses on different ideas which can be turned into social enterprises which are mainly related to eco-friendly developments.

4. Social entrepreneurship: A growing trend in Indian Economy (2012) by Dr.Pratap Singh. In this particular research, it has been mentioned that there is a broad scope for social entrepreneurships in India due to its large employment possibilities. Also, a growing trend as many entrepreneurs are coming with ideas of business that is all inclusive i.e. social as well as Economic factors. It also highlights how social entrepreneurships are slowly and steadily revolutionizing the less privileged sections of India. Due to these rapid changes in peoples' mindsets, big investor firms are also taking interest in social enterprises for profits but with a social objective and vision.

\section{Research design:-}

This research is a descriptive study done via surveys conducted among a few social enterprises and through reviewing previously done researches'. Primary data has been conducted by ways of a structured questionnaire which was circulated among close to 45 owners and beneficiaries of socially oriented businesses, out of which credible data was received from 28 respondents, which has been used in this research paper. The secondary data has been collected by referring to researches, articles and news clips based on social entrepreneurship. 


\section{Data interpretation:-}

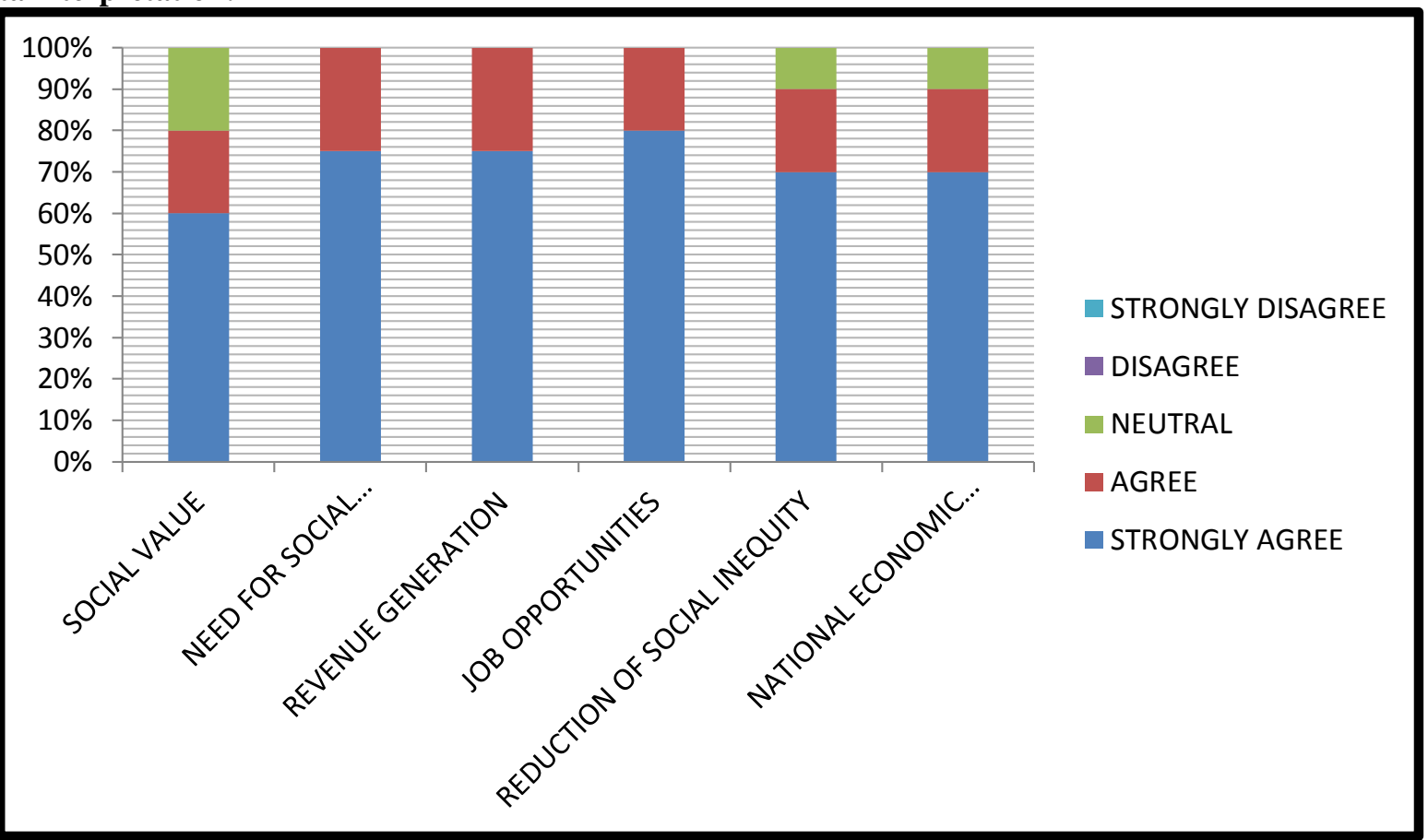

Based on the survey, it can be observed that social entrepreneurships certainly has major scope and can largely contribute to economic development, as social entrepreneurship provides job opportunities, especially in the lower level, thereby providing a livelihood to them. A majority of people opine that social entrepreneurship's have the ability to develop further more with government intervention and support. Depending on the statistical findings, the research brings out facts that even though social enterprises have low social value in terms of the brand or in terms of the mindset of people, it surely has larger scope for job opportunities and in turn for nation building. The research also shows that social enterprises have revenue generation capabilities specifically in terms of their socially produced products or its services. Another major finding has been the reduction in social inequality that is being faced by the people or the beneficiaries of the businesses. Hence such facts and findings brings about a solid need for more social enterprises in the country which not only brings about a change in the lives of people but also brings in a tremendous uplifting in the Nation's overall Development.

\section{Conclusion and recommendation:-}

$>\quad$ Social entrepreneurships are being accepted and recognized largely and the government is also putting in effort and initiatives to help entrepreneurs. Development of social entrepreneurship become a driving force for human development as due to many social enterprises, artisans and craftmans, disabled people, people of lower economic background, etc. have got opportunities to develop and mould themselves into better human beings and create a livelihood in the era of globalization. Many social entrepreneurs have imbibed the values of social welfare in their business which is bringing changes in the society. In many cases, it's the attitude of people towards such enterprise that become a drawback. Educating and empowering people to come out of the negligent and denial phase will lead to better and smooth functioning of such business.

$>\quad$ With the economic or revenue generating aspect, definitely, social entrepreneurships are providing great job opportunities to different communities, taking and e.g. " miracle couriers" which is providing jobs to the low income deaf men and women. Such enterprises are definitely the need for any developing nation so as to make each of its citizens achieve financial independence. 


\section{Bibliography:-}

1. Impact of social entrepreneurships in emerging economies, Indian CSR network by Manisha Bhatia

2. Social entrepreneurship in India, by Nikhil Menon, ET bureau dated 20 Feb, 2009

3. Opportunities for social entrepreneurs in India, by Samiksha Jain

4. Social entrepreneurship: A growing trend in Indian Economy (2012) by Dr.Pratap Singh

5. https://en.wikipedia.org/wiki/Social_entrepreneurship

6. https://www.ashoka.org/en/focus/social-entrepreneurship

7. https://www.investopedia.com/terms/s/social-entrepreneur.asp

8. www.journaliji.org/index.php/iji/article/view/20

9. indiacsr.in

10. https://www.entrepreneur.com/article/299141 